\title{
Effects of a Cover Crop on Splash Dispersal of Colletotrichum acutatum Conidia
}

\author{
N. Ntahimpera, M. A. Ellis, L. L. Wilson, and L. V. Madden
}

Department of Plant Pathology, The Ohio State University, Ohio Agricultural Research and Development Center (OARDC), Wooster 44691. Accepted for publication 10 March 1998.

\section{ABSTRACT}

Ntahimpera, N., Ellis, M. A., Wilson, L. L., and Madden, L. V. 1998. Effects of a cover crop on splash dispersal of Colletotrichum acutatum conidia. Phytopathology 88:536-543.

A rain simulator, with generated rains of 11 and $30 \mathrm{~mm} / \mathrm{h}$, was used to determine the effect of a cover crop or intercrop on the splash dispersal of Colletotrichum acutatum conidia. Dispersal through sudangrass, which can be used as a 'living mulch', was tested at two planting densities (140 or $280 \mathrm{~kg} / \mathrm{ha}$ ) and two heights (5 and $20 \mathrm{~cm}$ ) and compared with a control consisting of a bare soil. Dispersal of $C$. acutatum conidia was assessed by counting colonies formed from spore-bearing splash droplets deposited in sheltered petri plates containing a selective medium. Both a cover crop and rain intensity significantly affected splash dispersal as measured by the interpolated total number of colonies (denoted by $\Sigma$ ) from 0 to 72 $\mathrm{cm}$ from the inoculum source and in a time span of $61 \mathrm{~min}$ of generated rain $(P<0.001)$. However, there was no significant interaction of cover crop and intensity $(P>0.90)$. Dispersal with a $30-\mathrm{mm} / \mathrm{h}$ rain was higher than dispersal with a $11-\mathrm{mm} / \mathrm{h}$ rain, and presence of a cover crop significantly reduced dispersal compared with bare soil $(P<0.001)$. Of the treatments with sudangrass, cover crop planting density did not affect dispersal overall, but there was greater spore dispersal with the taller sudangrass at the higher planting density, due in part to the higher rate of water splashing with the tall grass compared with the short grass. Spore deposition in the petri plates could be functionally related to distance and time using a diffusion-type model, and parameter estimates could be used to explain the effects of cover crop on $\Sigma$. Although the relationship between cover crop properties and splash dispersal is complex, results show the potential beneficial effects of the cover crop on disease management.

Additional keywords: anthracnose, disease spread, Fragaria $\times$ ananassa, modeling, quantitative epidemiology, spatio-temporal dynamics.
Colletotrichum spp. cause economically important diseases on many crops (3) that are usually referred to as anthracnose diseases. Species in this genus are characterized, in part, by the rain-splash dispersal of conidia produced in acervuli $(21,50)$. Disease intensity of anthracnose for different crops has been associated with the occurrence of rainfall $(7-9,13,45)$, presumably because of the requirement of rain for dispersal, and the favorableness of wet plant surfaces for infection. We have previously shown the importance of rainfall in predicting incidence of anthracnose fruit rot of strawberry (Fragaria $\times$ ananassa) caused by Colletotrichum acutatum (25). In controlled studies, we have shown how properties of individual raindrops and distributions of raindrops over a given area affect the dispersal of conidia $(26,32,49)$ and the resulting fruit infection.

As found for other splash-dispersed pathogens, the flight of droplets with $C$. acutatum spores is very short $(\leq 15 \mathrm{~cm})(12,21,22)$. Thus, spores move to new infection sites primarily by a series of splashes and resplashes, in a process that can be modeled with an expanded diffusion equation (47). Because of the continual resplashing of droplets across the ground and through the canopy, the physical properties of the crop system (topography) have a very large influence on water transport and dispersal $(21,37)$. We have previously quantified the effects of variation in surface topography-surface roughness and strawberry plant density within rows - on dispersal of $C$. acutatum, both in the field and with a rain simulator $(5,21,24-26,46,49,50)$. For instance, increasing surface roughness, achieved by replacing plastic mulch with soil or straw ground cover, resulted in decreased spore dispersal and lower

Corresponding author: L. V. Madden; E-mail address: madden.1@osu.edu

Publication no. P-1998-0413-01R

This article is in the public domain and not copyrightable. It may be freely reprinted with customary crediting of the source. The American Phytopathological Society, 1998. disease incidence $(46,50)$. The same effect of surface roughness on splash dispersal was found for Phytophthora cactorum, the cause of strawberry leather rot (24). Mechanisms for the effect have been postulated to be loss of inoculum and spore-carrying droplets through surface infiltration, reduced transfer (reflection) of kinetic energy (or momentum) from the impacting drops to the splash droplets, and altered angle of the splash-droplet trajectories $(21,22$, 44,46,49). These results helped explain the increasing importance of anthracnose fruit rot as production systems switch from straw mulch to plastic cover (1), and led to the standard recommendation of maintaining deep straw mulch for the control of some fruit rot diseases of strawberry in perennial production systems $(15,24)$.

Population density of strawberry plants has a more complicated relationship to splash dispersal than does surface roughness. That is, although a general decrease in spore dispersal and disease incidence with increasing plant density was observed in controlled and field studies, the change was nonlinear $(5,23)$. At very low plant densities, an increase in density could result in an increase in dispersal $(5,46,50)$. Mechanisms for the plant-density effect on dispersal are partly related to those for surface roughness, but they include reduction in spore removal from the inoculum source, reduction in splash of spore-carrying droplets over the surface, and interception of spores by the plant canopy $(5,22)$.

Surface roughness and plant population density are two extreme categories of topography that can affect spore movement in splash droplets. Techniques for operationally describing the topography are different-standard deviation of surface elevation for roughness $(18,19)$, number of plants per unit row or area, or raindrop penetration of the canopy for strawberry density (5) - and there are inherent differences in spatial patterns. That is, one can consider the soil or mulch surface as a reasonably homogeneous area over which small-scale variation in elevation is assessed, whereas plant density for a row crop is clearly nonhomogeneous. There is, by definition, patchiness of plants both between rows and also within rows, and 
the degree of patchiness can change with changing plant density. There also is variation in leaf density, position, and angles within plants. Thus, to better characterize the mechanism of the splashdispersal process, information is needed on spore transport in relation to different levels of plant density over a more homogeneous area, in which changing density is achieved with less alteration of patchiness and structural properties of the plants than that achieved when varying strawberry density within rows. Such a study can be done using a grass cover crop.

With increasing interest in cover crops for horticultural reasons (e.g., weed control and soil moisture management) (33), intercropping has been suggested as a possible tactic for cultural control of some plant pathogens (42). It has been shown that disease incidence and severity are reduced in certain crop combinations (4, 6,43 ). In addition to potentially increasing roughness, an intercrop functions as a physical barrier, restricting movement of conidia between adjacent rows (40). Sudangrass and other plant species have been tested in strawberry production as a living mulch (cover crop) $(29,33)$ for a replacement of straw mulch. However, no experimental data are available to determine how sudangrass plant density would affect the splash dispersal of $C$. acutatum conidia or how the effects of rain on dispersal are modified by the cover crop.

The objective of this study was to determine how a cover crop alters the effects of rain intensity on splash dispersal. Splash dispersal of $C$. acutatum over a bare soil was compared with dispersal through sudangrass planted at two densities and at two heights. It was hypothesized that a cover crop would reduce dispersal at a given rain intensity compared with a soil surface, because of altered flight trajectories and removal of spores from the system $(36,47)$. An interaction between rain intensity and ground cover was not expected to occur, based on previous surface roughness and strawberry plant density results $(5,46,49)$. Preliminary results were previously reported (31).

\section{MATERIALS AND METHODS}

Rain generation system. The rain simulator developed at The Ohio State University, Ohio Agricultural Research and Development Center (34), was used to determine the effect of a cover crop (intercrop) on the splash dispersal of $C$. acutatum conidia. The system consisted of an upward-pointing and rotating wide-angle spray nozzle (Spraying Systems, Inc., Wheaton, IL) that produced a conical and uniform water-drop pattern over a $1.2 \times 1.2-\mathrm{m}$ area. The distance of drop fall was $4 \mathrm{~m}$ with a water pressure level of $69 \mathrm{kPa}$ at the nozzle orifice, which was maintained constantly with a precision flow valve. Two spray nozzles, $20 \mathrm{~W}$ and $35 \mathrm{~W}$, were used individually in this study to generate rains similar to those of natural rains of about 11 and $30 \mathrm{~mm} / \mathrm{h}$, respectively (26).

The cover crop (Sorghum bicolor var. sudanensis) cv. Trudan 8 was seeded in $52 \times 26 \times 7$-cm flats, with three rows per flat, in a greenhouse. The flats contained steam-sterilized soil mix (soil/peat moss, 5:1, by volume; supplemented with $150 \mathrm{~g}$ of 9-45-15 N-P-K fertilizer and lime). Planting densities of 280 and $140 \mathrm{~kg}$ of seed per ha were used, representing 1,575 and 787 plants per $\mathrm{m}^{2}$, respectively. In preliminary studies, it was found that competition effects greatly reduced plant growth and development at seeding densities greater than $280 \mathrm{~kg} / \mathrm{ha}$ (L. V. Madden, unpublished data); thus, no higher densities were tested. Four to six weeks after planting, sudangrass plants were cut at either a height of 5 or $20 \mathrm{~cm}$ from the soil surface. There were five experimental treatments, comprising the four combinations of sudangrass planting density and height (density/height) and a control. Specifically, treatments were bare soil (control treatment); sudangrass plants at $140 \mathrm{~kg} / \mathrm{ha}$ and $5 \mathrm{~cm}$ in height (140/5) or $20 \mathrm{~cm}$ in height (140/20); and sudangrass at $280 \mathrm{~kg} / \mathrm{ha}$ and $5 \mathrm{~cm}$ in height (280/5) or $20 \mathrm{~cm}$ in height (280/20). Four contiguous trays were used for each rain simulation in a $2 \times$ 2 pattern $(104 \times 52 \mathrm{~cm})$ to obtain an area of $5,408 \mathrm{~cm}^{2}$ of a cover crop. Plants and soil were discarded after each rain simulation test. For each rain simulation, sudangrass flats were put on a $1.5 \times$ $1.5-\mathrm{m}$ wood frame, and the remaining area was covered with sterilized soil up to the top of each flat.

Leaf area index (LAI) was estimated for each treatment with sudangrass using a LiCor model 3100 Area Meter (LiCor Inc., Lincoln, NE). Twenty plants of each of the four combinations of planting density and height were measured. Readings of individual plant area were recorded, and average plant area was calculated. LAI of each replication was estimated by multiplying average plant area (square meters) by the number of plants per square meter. Mean LAI values of the four sudangrass treatments were 0.22 (standard error $[\mathrm{SE}]=0.003), 1.07(\mathrm{SE}=0.013), 0.34(\mathrm{SE}=$ $0.020)$, and $1.82(\mathrm{SE}=0.107)$, for the $140 / 5,140 / 20,280 / 5$, and 280/20 treatments, respectively.

Inoculum production. The isolate of $C$. acutatum (ATCC 90170) used in this experiment was the same as in the previous studies $(26,32,45,49,50)$. To prepare infected source fruits for each run of the experiment, detached, immature (green-to-white stage) fruits from greenhouse-grown strawberry plants (cultivar Midway) were washed with deionized water, surface-sterilized in $70 \%$ ethanol for $60 \mathrm{~s}$, rinsed with deionized water, dried, and placed on elevated screens (6-mm mesh) contained in 5-liter plastic containers. The containers were filled with approximately $700 \mathrm{ml}$ of deionized water. The pedicel of each fruit was inserted through the mesh of the metal screen and immersed in water to minimize fruit desiccation. Fruits were then sprayed to runoff with an inoculum suspension of $10^{5}$ conidia per $\mathrm{ml}$. The containers were closed and incubated at $25^{\circ} \mathrm{C}$ for $24 \mathrm{~h}$ to ensure infection (45), after which time, the lids were removed and the fruits kept at $25^{\circ} \mathrm{C}$ for 7 days to ensure lesion development and sporulation. This regime was previously shown to result in approximately $2 \times 10^{8}$ conidia per fruit (26).

Sheltered gravity samplers and spore deposition. To determine splash dispersal of conidia, the wood frame $(1.5 \times 1.5 \mathrm{~m})$ was placed immediately below the rain generator and covered evenly with sterilized standard soil mix as previously described $(26,32)$ or with the flats of sudangrass. Five inoculated fruits (described above) with sporulating lesions were clustered in one corner of the experimental area, which was adjacent to the sudangrass (when these treatments were tested). Petri plates $(6 \mathrm{~cm}$ in diameter) containing a selective medium for Colletotrichum (10) were labeled and positioned, with the lids removed, under metal rain shields at $12,27,42,57$, and $72 \mathrm{~cm}$ (one plate for each distance) from the inoculum source $(21,49)$. These 'gravity' samplers had rain shields to prevent direct interception of rain, so that only splashed water drops were sampled (Fig. 1 in literature citation 49). To test for contamination, one plate was placed under rain shelters and exposed to $1 \mathrm{~min}$ of generated rain before introducing the source fruits.

Starting at 0 min into a simulated rain, plates were exposed to splashing water every $5 \mathrm{~min}$ for 1 -min periods, for a total rain duration of $61 \mathrm{~min}$. New plates were used for each time period. After exposure, plates were covered with lids and incubated at $25^{\circ} \mathrm{C}$ for 2 days. The plates were then transferred to a refrigerator at $6^{\circ} \mathrm{C}$ for 2 to 3 days. For each plate, colonies were counted with the aid of a magnifying plate counter (New Brunswick Scientific Co., New Brunswick, NJ). Simulations were done at least three times for each treatment. Periodically, representative colonies were transferred to potato dextrose agar medium to obtain greater sporulation for examination of morphological characteristics and positive fungal identification.

Volume of water splashed. Volume (mass) of water splashed $\left(R_{S}\right.$; milliliters [grams] per square centimeter per hour) was determined with gravity samplers in separate runs of the rain simulator without inoculum $(26,32)$. Three to five sheltered gravity samplers were placed over the experimental area. Petri plates $(9 \mathrm{~cm}$ in diameter) with selective medium to Colletotrichum (10) were labeled and weighed immediately before use. At 12 and $27 \mathrm{~min}$ into a simulated rain, plates were placed under the rain shields for 2 min of rain exposure. Plates were collected and immediately weighed 

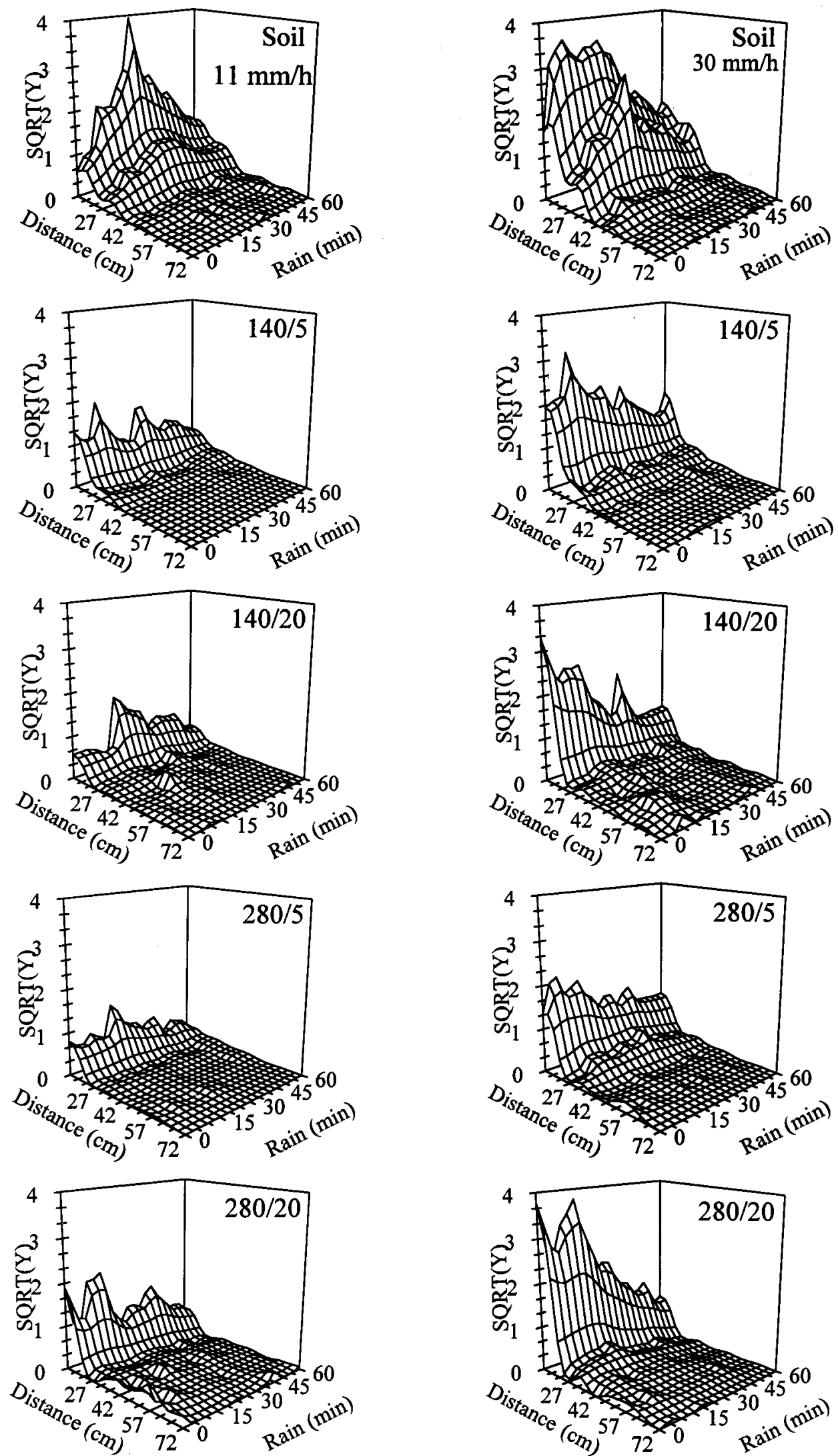

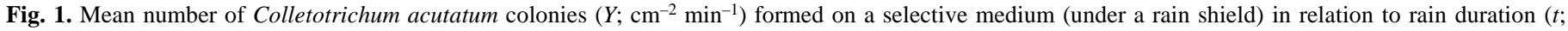
$\mathrm{min}$ ) and distance $(s ; \mathrm{cm})$ from the inoculum source for five ground cover treatments at two rain intensities, $11 \mathrm{~mm} / \mathrm{h}$ (left column) and $30 \mathrm{~mm} / \mathrm{h}$ (right column). Square root of $Y$ (SQRT[Y]) was used to better illustrate the data at $42 \mathrm{~cm}$ and beyond, where colony density was low. Treatments (labeled inside each graph) consisted of bare soil (control) and combinations of sudangrass planting density (140 or $280 \mathrm{~kg}$ of seeds per ha) and height (5 or $20 \mathrm{~cm})$, resulting in labels of $140 / 5,140 / 20,280 / 5$, and 280/20. 
again to determine weight gain due to water splashed into each plate. Because of the unit density of water, weight changes could be used to determine water volume changes in plates. Controls consisted of three plates with media that were weighed at the same time, but not exposed to rain (26). Average weight loss of the controls, due to evaporation, was used to correct results for tested plates. Splash for each treatment (sudangrass density/height combinations and the bare soil control) was tested at least three times (with a new soil each time) in a random order.

Data analysis. Colony density in petri plates, converted to units of area and time ( $Y$; numbers per square centimeter per minute), was determined for each distance from the inoculum source (e.g., $12 \mathrm{~cm}$ ), time since the start of the simulated rain (rain duration; e.g., $15 \mathrm{~min}$ ), rain intensity, treatment, and repetition. $Y$ is proportional to the deposition flux density of conidia (47). Assuming equal dispersal in all directions because of lack of air flow, the interpolated total number of colonies $(\Sigma)$ during each 61-min period over a circular area with a radius of $72 \mathrm{~cm}$ (the maximum distance measured) was estimated by numerical integration over both the distance and time domains. The integration was done following Simpson's $3 / 8$ rule with the SURFER software (Golden Software Inc., Golden, CO). Standard errors of the means for each treatment were calculated prior to subsequent transformation and analyses.

Analysis of variance (ANOVA) was performed on the total number of colonies $(\Sigma)$. To stabilize variances, $\Sigma$ was transformed to $\Sigma^{1 / 5}$ before ANOVA (26). Orthogonal contrasts of the treatment means were calculated by partitioning the treatment sum of squares into four components. The tested contrasts were control versus the sudangrass treatments; $140 \mathrm{~kg} / \mathrm{ha}$ versus $280 \mathrm{~kg} / \mathrm{ha}$ (planting density of sudangrass seeds); $5 \mathrm{~cm}$ versus $20 \mathrm{~cm}$ (height of sudangrass); and the interaction of density and height (i.e., 140/5 + $280 / 20$ versus $140 / 20+280 / 5$ ). The experiment was a randomized complete block design with repetition (block), rain intensity, and treatment as experimental factors.

ANOVA was also used to assess the volume of water splashed, after first taking the square root of $R_{S}$ to stabilize variances. The same four contrasts were calculated. Experimental design was a repeated measures factorial with repetition (block), rain intensity, and treatment as "crossed" factors, and time as the repeated measure.

The diffusion-type model of Yang et al. (47) was fitted to the colony data to describe colony numbers per unit area and time $(Y)$ as a function of rain duration $(t ; \mathrm{min})$ and distance from the source $(s ; \mathrm{cm})$ :

$$
Y=\left[Q^{\prime} /(4 \pi \alpha t)\right] \cdot \exp \left[-\left(s^{2} /(4 \alpha t)\right)\right] \cdot \exp (-\gamma t)
$$

Parameters of the model are $Q^{\prime}\left(\mathrm{min}^{-1}\right)$, representing the initial release of spores from the inoculum source, which is related to inoculum density on the fruit and properties of the simulated rain (47); $\alpha\left(\mathrm{cm}^{2} \mathrm{~min}^{-1}\right)$, which is inversely related to the steepness of the spore-deposition gradient and a measure of the average flight distance of splash droplets; and $\gamma\left(\mathrm{min}^{-1}\right)$, which represents the rate of spore loss from the system (e.g., infiltration of spores through the soil). Parameters were estimated by nonlinear least squares with the NLIN procedure (SAS Institute Inc., Cary, NC) using the Marquardt algorithm. All three parameters were estimated for the soil-cover controls. However, since $Q^{\prime}$ is presumed to be dependent on rain properties and not the surface, only $\alpha$ and $\gamma$ were estimated for the other treatments. The estimate of $Q^{\prime}$ from the control at the same rain intensity was used as a constant in equations for sudangrass. This helped ensure precise estimation of the other parameters with data sets characterized by low $Y$ (described in Results).

\section{RESULTS}

Colonies. The spatial and temporal pattern of mean colony density $(Y)$ for each treatment is illustrated in Figure 1. As with previous studies $(5,26,32,49), Y$ generally declined with distance from inoculum source at any rain duration and decreased from a maxi- mum over time, although the maximum sometimes was for the first sampling period (0 to $1 \mathrm{~min}$ ). The presence of sudangrass plants somewhat affected the general pattern of colony density. Except for the bare soil, there were few colonies beyond $27 \mathrm{~cm}$. For controls, the maximum $Y$ was reached later than for sudangrass. Also, $Y$ generally was higher for the $30-\mathrm{mm} / \mathrm{h}$ than for the $11-\mathrm{mm} / \mathrm{h}$ rain intensity.

ANOVA performed on the fifth-root transformation of the estimated number of colonies $\left(\Sigma^{1 / 5}\right)$ showed highly significant $(P<$ 0.001 ) (Table 1) effects of rain intensity and treatment. There was no significant block (experiment repetition; $P>0.70$ ) effect, and the interaction of treatment and rain intensity was clearly not significant $(P>0.90)$. Contrast analysis showed that mean estimated $\Sigma^{1 / 5}$ of the control treatment (bare soil) was significantly different from means of the sudangrass treatments (control versus others, Table 1), whereas the cover-crop planting density did not have an overall significant effect on colony numbers (140 versus 280 , Table 1). Sudangrass height (5 versus 20 ) marginally affected the number of colonies $(P=0.06)$, and the density $\times$ height interaction within the treatment main effect was significant $(P<0.05)$, indicating that the impact of plant height on the estimated $\Sigma^{1 / 5}$ depended on planting density.

Since block was not significant (Table 1), means across experiment repetitions could be presented and compared (Table 2). The mean estimated $\Sigma$ for the $30-\mathrm{mm} / \mathrm{h}$ rain intensity was more than double the estimated $\Sigma$ for $11 \mathrm{~mm} / \mathrm{h}$. Treatment means averaged over the two intensities can be made to evaluate ground cover treatments, because of the nonsignificant interaction (Table 1). The mean estimated $\Sigma$ for the soil control treatment was from two to five times greater than for the other treatments (Table 1), in agreement with the significant first contrast (Table 1). The lowest estimated $\Sigma$ (or $\Sigma^{1 / 5}$ ) was for the high planting density of sudangrass at the low height (280/5), and the highest estimated $\Sigma$ (of those treatments with sudangrass) was for $280 / 20$, which is in agreement with the significant density $\times$ height contrast (Table 1 ). For the low planting density, on the other hand, height did not influence estimated $\Sigma$. LAI of sudangrass was not directly related to estimated $\Sigma$.

Intensity of water splashed. Volume of water splashed $\left(R_{S}\right.$; milliliters per square centimeter per hour) was significantly $(P<$ 0.01 ) affected by rain intensity and treatment (Table 3 ). The $30-$ $\mathrm{mm} / \mathrm{h}$ rain splashed about $40 \%$ more water than the $11-\mathrm{mm} / \mathrm{h}$ rain (Table 4), $0.17(\mathrm{SE}=0.016)$ versus $0.12(\mathrm{SE}=0.017) \mathrm{ml} \mathrm{cm}^{-2} \mathrm{~h}^{-1}$. The interaction between rain intensity and ground cover treatment was not significant $(P>0.70)$. Contrast analysis of the treatment means showed that the bare soil (control) treatment had significantly lower $R_{S}$ than the others. Sudangrass height (contrast 5

TABLE 1. Degrees of freedom (df), mean square error (MSE), and significance level $(P)$ for an analysis of variance (ANOVA) of the effects of a cover crop and rain intensity on splash dispersal of Colletotrichum acutatum spores assessed as an estimated total number of colonies formed in petri plates $(\Sigma)^{\mathrm{a}}$

\begin{tabular}{lrrr}
\hline Source of variation & df & MSE & $P$ \\
\hline Repetition (block) $^{\text {Intensity }}{ }^{\mathrm{b}}$ & 3 & 0.80 & 0.767 \\
Treatment $^{\mathrm{c}}$ & 1 & 47.19 & $<0.001$ \\
Soil vs. others $^{\mathrm{d}}$ & 4 & 22.33 & $<0.001$ \\
Density $\left(140\right.$ vs. 280) $^{\mathrm{d}}$ & 1 & 67.64 & $<0.001$ \\
Height $\left(5\right.$ vs. 20) $^{\mathrm{d}}$ & 1 & 0.00 & 0.999 \\
Density $\times$ height $^{\mathrm{d}}$ & 1 & 7.91 & 0.064 \\
Intensity $\times$ treatment $_{\text {Error }}$ & 1 & 11.96 & 0.025 \\
- & 4 & 0.17 & 0.987 \\
\hline
\end{tabular}

a $\Sigma$ was determined by numerical integration over distances of 0 to $72 \mathrm{~cm}$ and times (rain duration) of 0 to $61 \mathrm{~min}$. $\Sigma^{1 / 5}$ for individual repetitions of each treatment and rain intensity were used in the ANOVA to stabilize variances. ${ }^{\mathrm{b}}$ Intensity was $11 \mathrm{~mm} / \mathrm{h}(20 \mathrm{~W}$ nozzle) or $30 \mathrm{~mm} / \mathrm{h}$ (35W nozzle).

${ }^{\mathrm{c}}$ Bare soil (control) and combination of sudangrass planting density (140 or $280 \mathrm{~kg}$ of seeds per ha) and height (5 or $20 \mathrm{~cm}$ ).

${ }^{\mathrm{d}}$ Contrasts of treatment means. 
versus 20$)$ also significantly $(P<0.001)$ affected $R_{S}$ (Table 3 ), with higher mean $R_{S}$ for the tall plants compared with the short plants (Table 4). Density (140 versus 280 ) and the height $\times$ density interaction contrasts (within the treatment main effect) were not significant $(P>0.30)$.

$R_{S}$ was also significantly affected by the time of water collection within the simulated rains $(P<0.05)$ (Table 3$)$. However, the time $\times$ intensity interaction was not significant $(P>0.90)$, indicating that time did not affect the difference in $R_{S}$ between the two rain intensities. The interaction between time and treatment was significant $(P<0.01)$, however. Inspection of the mean $R_{S}$ values indicated that this interaction primarily was due to a small but consistent increase in $R_{S}$ over time mostly for the 140/5 treatment and not the others (Table 4). Thus, differences in $R_{S}$ among treatments can be assessed based on means across time and intensity.

Diffusion-type model equation. The diffusion-type model (47) gave a satisfactory fit to the data of $Y$ in relation to rain duration $(t)$ and distance from the inoculum source $(s)$ (Table 5). Values of the coefficient of determination $\left(r^{2}\right)$ were all greater than 0.60 and were mostly above 0.80 . For the $11-$ and $30-\mathrm{mm} / \mathrm{h}$ rain intensities, $r^{2}$ was 0.89 and 0.87 , respectively, for bare soil (control). The poorest fits were with the short sudangrass plants. As with previous work (26), the estimated spore release (removal) parameter $\left(Q^{\prime}\right)$ was dependent on rain intensity. Estimated $Q^{\prime}$ for $30 \mathrm{~mm} / \mathrm{h}$ $\left(1.9 \times 10^{4} \mathrm{~min}^{-1}\right)$ was about $20 \%$ higher than for $11 \mathrm{~mm} / \mathrm{h}(1.6 \times$ $10^{4} \mathrm{~min}^{-1}$ ) (Table 5).

The estimated parameter for the splash-droplet trajectory length, $\alpha$, was related to rain intensity, with higher values of estimated $\alpha$ for $30 \mathrm{~mm} / \mathrm{h}$ than for $11 \mathrm{~mm} / \mathrm{h}$ (Table 5). For the $30-\mathrm{mm} / \mathrm{h}$ rain, estimated values of $\alpha$ were about the same for all sudangrass treatments (ranging from 2.1 to $2.5 \mathrm{~cm}^{2} \mathrm{~min}^{-1}$ ), but lower than for the bare soil $\left(3.8 \mathrm{~cm}^{2} \mathrm{~min}^{-1}\right)$. Estimated values of $\gamma$ (reflecting the rate of spore loss) were larger for treatments with cover crop (sudangrass) than for the bare soil at this high rain intensity. The 280/20 treatment had a slightly higher estimated $\alpha$ than other sudangrass treatments, while estimated $\gamma$ was a little smaller than others. This was consistent with results for $\Sigma$ with the $280 / 20$ treatment. The

TABLE 2. Estimated number of colonies $(\Sigma)$ of Colletotrichum acutatum $^{\text {a }}$ formed in petri plates containing selective medium after splash dispersal of spores with two rain intensities (11 and $30 \mathrm{~mm} / \mathrm{h}$ ) for five ground cover treatments

\begin{tabular}{|c|c|c|c|c|c|c|}
\hline \multirow[b]{3}{*}{ Treatment $\mathrm{t}^{\mathrm{b}}$} & \multicolumn{4}{|c|}{ Intensity } & & \\
\hline & \multicolumn{2}{|c|}{$11 \mathrm{~mm} / \mathrm{h}$} & \multicolumn{2}{|c|}{$30 \mathrm{~mm} / \mathrm{h}$} & \multicolumn{2}{|c|}{ Mean $^{c}$} \\
\hline & $\Sigma$ & $\Sigma^{1 / 5}$ & $\Sigma$ & $\Sigma^{1 / 5}$ & $\Sigma$ & $\Sigma^{1 / 5}$ \\
\hline Soil & $\begin{array}{c}5.55 \times 10^{5} \\
\left(5.30 \times 10^{4}\right)^{d}\end{array}$ & 14.06 & $\begin{array}{l}11.3 \times 10^{5} \\
\left(1.83 \times 10^{5}\right)\end{array}$ & 16.14 & $\begin{array}{c}8.41 \times 10^{5} \\
\left(1.40 \times 10^{5}\right)\end{array}$ & 15.1 \\
\hline $140 / 5$ & $\begin{array}{c}1.31 \times 10^{5} \\
\left(3.72 \times 10^{4}\right)\end{array}$ & 10.38 & $\begin{array}{c}3.88 \times 10^{5} \\
\left(8.06 \times 10^{4}\right)\end{array}$ & 13.03 & $\begin{array}{c}2.60 \times 10^{5} \\
\left(6.98 \times 10^{4}\right)\end{array}$ & 11.7 \\
\hline $140 / 20$ & $\begin{array}{c}1.15 \times 10^{5} \\
\left(7.77 \times 10^{3}\right)\end{array}$ & 10.28 & $\begin{array}{c}3.70 \times 10^{5} \\
\left(1.52 \times 10^{5}\right)\end{array}$ & 12.63 & $\begin{array}{c}2.43 \times 10^{5} \\
\left(8.86 \times 10^{4}\right)\end{array}$ & 11.5 \\
\hline $280 / 5$ & $\begin{array}{c}0.88 \times 10^{5} \\
\left(4.94 \times 10^{4}\right)\end{array}$ & 9.01 & $\begin{array}{c}2.65 \times 10^{5} \\
\left(1.26 \times 10^{5}\right)\end{array}$ & 11.75 & $\begin{array}{c}1.64 \times 10^{5} \\
\left(6.50 \times 10^{4}\right)\end{array}$ & 10.2 \\
\hline $280 / 20$ & $\begin{array}{c}2.55 \times 10^{5} \\
\left(7.39 \times 10^{5}\right)\end{array}$ & 11.80 & $\begin{array}{c}5.44 \times 10^{5} \\
\left(1.18 \times 10^{5}\right)\end{array}$ & 13.91 & $\begin{array}{c}3.79 \times 10^{5} \\
\left(8.34 \times 10^{4}\right)\end{array}$ & 12.7 \\
\hline Mean & $\begin{array}{c}2.41 \times 10^{5} \\
\left(4.81 \times 10^{4}\right)\end{array}$ & 11.90 & $\begin{array}{c}5.75 \times 10^{5} \\
\left(1.02 \times 10^{5}\right)\end{array}$ & 13.66 & & \\
\hline
\end{tabular}

a Determined by numerical integration over 0 to $72 \mathrm{~cm}$ and 0 to 61 min using Simpson's $3 / 8$ rule. For analysis of variance (Table 1 ), estimated $\Sigma$ was transformed to $\Sigma^{1 / 5}$ for each repetition of each treatment and rain intensity to stabilize variances (24). Data shown are means of estimated $\Sigma$ or of $\Sigma^{1 / 5}$. By definition, the mean $\Sigma$ raised to the $1 / 5$ power does not equal the mean of the individual $\Sigma^{1 / 5}$ observations.

b Bare soil (control) and combination of sudangrass planting density (140 or $280 \mathrm{~kg}$ of seeds per ha) and height $(5$ or $20 \mathrm{~cm})$, identified with a density/height label.

c Means across the two rain intensities.

d Standard error in parentheses. low standard error values indicate that these parameters were precisely estimated.

For the $11-\mathrm{mm} / \mathrm{h}$ simulated rain, estimated values of $\alpha$ were erratic, sometimes less than for the bare soil control (for 140/20 and 280/5 treatments) and sometimes greater (Table 5). Estimated values of $\gamma$ were larger for the cover crop than for the bare soil. However, contrary to the $30-\mathrm{mm} / \mathrm{h}$ intensity, larger estimates of $\alpha$ were associated with larger estimates of $\gamma$; thus, the total number of colonies was lower for all cover crop treatments than for the control (Table 2), even when estimated $\alpha$ was larger in the cover crop than the control.

\section{DISCUSSION}

Results obtained in this study showed that splash dispersal of $C$. acutatum conidia, as measured by colony density at a given distance from the source and rain duration $(Y)$, and estimated total number of colonies $(\Sigma)$ increased with rain intensity and decreased with the presence of sudangrass plants. Within the four cover crop treatments, the effect of plant population density on estimated $\Sigma$ (more specifically, $\Sigma^{1 / 5}$ ) was characterized by an interaction of planting density and height. Specifically, the high planting density and tall plant treatment (280/20) had more colonies than the high density and short plant (280/5) treatment, whereas the low planting density (140/5 and 140/20) treatments had intermediate numbers of colonies (Table 2). Furthermore, differences in estimated $\Sigma$ among the ground cover treatments did not depend on rain intensity, as indicated by nonsignificant interaction. This was expected, because there was no intensity $\times$ treatment interaction with previous tests of surface roughness (soil, straw, and plastic) and plant density (different LAI index) on splash dispersal using the rain simulator $(5,21,22,46,49,50)$.

The estimated parameters of equation 1 for colony density $(Y)$ in relation to distance and time can be used to help explain the splash-dispersal process. That is, although no interaction was obtained between rain intensity and treatment for estimated (transformed) total number of colonies (i.e., $\Sigma^{1 / 5}$ ), the estimates of $\alpha$ and $\gamma$ (Table 5) indicated that rain intensity differentially affected the dispersal process. With the $30-\mathrm{mm} / \mathrm{h}$ rain, droplet flight trajectory

TABLE 3. Degrees of freedom (df), mean square error (MSE), and significance level $(P)$ for an analysis of variance (ANOVA) of the effects of a cover crop and rain intensity on volume of water splashed into petri plates ${ }^{\mathrm{a}}$ at two times

\begin{tabular}{|c|c|c|c|}
\hline Source of variation & df & MSE & $P$ \\
\hline Repetition (block) & 2 & 0.0005 & 0.950 \\
\hline Intensity ${ }^{b}$ & 1 & 0.0992 & 0.004 \\
\hline Treatment $^{\mathrm{c}}$ & 4 & 0.1532 & $<0.001$ \\
\hline Soil vs. others ${ }^{d}$ & 1 & 0.1762 & $<0.001$ \\
\hline Density (140 vs. 280$)^{\mathrm{d}}$ & 1 & 0.0019 & 0.651 \\
\hline Height $(5 \text { vs. } 20)^{\mathrm{d}}$ & 1 & 0.4278 & $<0.001$ \\
\hline Density $\times$ height $^{\mathrm{d}}$ & 1 & 0.0068 & 0.400 \\
\hline Intensity $\times$ treatment & 4 & 0.0043 & 0.757 \\
\hline Error $(A)^{\mathrm{e}}$ & 18 & 0.0091 & \\
\hline Time $^{f}$ & 1 & 0.0014 & 0.042 \\
\hline Time $\times$ intensity & 1 & 0.0000 & 0.937 \\
\hline Time $\times$ treatment & 4 & 0.0014 & 0.008 \\
\hline Time $\times$ intensity $\times$ treatment & 4 & 0.0004 & 0.253 \\
\hline Error $(B)^{g}$ & 18 & 0.0003 & \\
\hline
\end{tabular}

a Analysis of the volume of water splashed $\left(R_{S} ; \mathrm{ml} \mathrm{cm}^{-2} \mathrm{~h}^{-1}\right)$ was based on the square root of $R_{S}$ to stabilize variances.

b Intensity was $11 \mathrm{~mm} / \mathrm{h}$ (20W nozzle) or $30 \mathrm{~mm} / \mathrm{h}$ ( $35 \mathrm{~W}$ nozzle).

c Treatments were bare soil (control treatment); sudangrass plants at $140 \mathrm{~kg}$ of seeds per ha at planting and $5-\mathrm{cm}$ height $(140 / 5)$ or $20-\mathrm{cm}$ height $(140 / 20)$; and sudangrass at $280 \mathrm{~kg}$ of seeds per ha at planting and $5-\mathrm{cm}$ height (280/5) or 20-cm height (280/20).

d Contrasts of treatment means.

e Error (A) is used for testing effects of block, intensity, and treatment (including contrasts), and the intensity $\times$ treatment interaction.

f $R_{S}$ determined at either 12 or 27 min into a generated rain.

$\mathrm{g}$ Error (B) used for testing time and interactions involving time. 
(represented by estimated $\alpha$ ) was equal for all cover crop treatments (approximately $2.2 \mathrm{~cm}^{2} \mathrm{~min}^{-1}$ ), but was shorter than that of the control soil $\left(3.8 \mathrm{~cm}^{2} \mathrm{~min}^{-1}\right)$. The rates of spore loss (represented by estimated $\gamma$ ) were not the same for all cover crop treatments, but they were all greater than that of the control. For $11 \mathrm{~mm} / \mathrm{h}$, estimated $\gamma$ was also larger for the cover crop treatments compared with the control. However, unlike the situation for $30-\mathrm{mm} / \mathrm{h}$ rains, estimated $\alpha$ was more variable, with some cover crop treatments having a larger estimated $\alpha$ than that of the control. These cases were associated with the larger spore loss rates (estimated $\gamma$ ), and the combined effect was fewer total colonies for all sudangrass treatments compared with the control at $11 \mathrm{~mm} / \mathrm{h}$. Thus, there was no interaction of treatment and rain intensity for the overall measure of dispersal $\left(\Sigma^{1 / 5}\right)$, even though the components of dispersal were differentially affected by intensity in the different treatments. Yang et al. (47) previously showed that $\alpha$ decreases and $\gamma$ increases with increasing surface roughness, when plastic, soil, and straw were compared, which is qualitatively consistent with our results. Yang and Madden (46) also directly measured transport of splash droplets (without spores) and found that estimated trajectory length $(\alpha)$ decreased with increasing roughness.

Our results are in general agreement with previous studies that showed a pronounced effect of topography (including plant density) on the splash dispersal of $C$. acutatum $(5,21,22,46,49,50)$. All of the sudangrass treatments were rougher-that is, they had greater variation in height across the surface (18) due to the presence or absence of a plant at any given location - than the bare soil control, and the cover crop treatments had lower spore dispersal by rain splash than the control. As discussed by Madden (21) and Yang et al. (49), increased roughness is associated with altered droplet flight trajectories, increased transfer (reflection) of kinetic energy from the impacting drops to the splash droplets, and increased removal of spores from the system. Presence of a plant canopy also could serve as a barrier to droplet movement $(5,22$, 23 ), and consequently, could result in reduction in spore removal from the inoculum source and interception of spores by the plant canopy. However, when a cover crop was present in our current study, increasing density of plants (number per unit area) or height of the plants did not lead to decreased dispersal. In fact, the greatest dispersal of the treatments with a cover crop was associated with the largest LAI (280 plants per ha/20 cm in height [280/20]) (Table 2; Fig. 1). In this sense, the cover crop system here has some similarity to the strawberry density system, because it was previously shown that there is not a universal decrease in spore dispersal as strawberry plant density increases (5). In fact, previously reported results for both rain simulation (5) and field studies (23) show that an intermediate strawberry density may have the greatest dispersal of spores by rain splash.

The splashing of rain on the soil surface within the cover crop can increase our understanding of the dispersal results. As indicated by Huber et al. (20) and Madden et al. (26), the intensity of splashed rain $\left(R_{S}\right)$ is one measure of the transport of water droplets across a surface. $R_{S}$ is determined by the properties of the incident rain (e.g., kinetic energy) and the overall topography of the system. Our results support the finding that, with rains of a single type (e.g., showers), $R_{S}$ increases with rain intensity (26). This is because drop sizes increase with increasing intensity (41), and larger drops splash more water than smaller drops $(20,48)$. Madden (21) also showed that there was a lower mean $R_{S}$ over a straw mulch than over soil; however, no differences in mean $R_{S}$ between soil and plastic could be distinguished, even though spore dispersal was considerably higher with the latter $(49,50)$. Thus, $R_{S}$ may be one useful assessment of total transport of water droplets, but

TABLE 5. Estimated parameters and standard errors of the diffusion-type model (equation 1) ${ }^{\mathrm{a}}$ fitted to the mean number of colonies of Colletotrichum acutatum $\left(Y ; \mathrm{cm}^{-2} \mathrm{~min}^{-1}\right)$ in relation to rain duration $(t ; \mathrm{min})$ and distance from inoculum source $(s ; \mathrm{cm})$ for five ground cover treatments and two rain intensities, together with the coefficients of determination $\left(r^{2}\right)$

\begin{tabular}{llccc}
\hline & & \multicolumn{2}{c}{ Estimated parameters } & \\
\cline { 3 - 4 } Rain intensity & Treatment $^{\mathrm{b}}$ & $\alpha\left(\mathrm{cm}^{-2} \mathrm{~min}^{-1}\right)$ & $\gamma\left(\mathrm{min}^{-1}\right)$ & $r^{2}$ \\
\hline $11 \mathrm{~mm} / \mathrm{h}$ & Soil & $1.01(0.12)^{\mathrm{c}}$ & $0.030(0.007)$ & 0.89 \\
& $140 / 5$ & $1.67(0.14)$ & $0.123(0.008)$ & 0.61 \\
& $140 / 20$ & $0.62(0.04)$ & $0.066(0.003)$ & 0.72 \\
& $280 / 5$ & $0.67(0.04)$ & $0.087(0.004)$ & 0.68 \\
$30 \mathrm{~mm} / \mathrm{h}$ & $280 / 20$ & $1.47(0.10)$ & $0.083(0.004)$ & 0.76 \\
& Soil & $3.84(0.42)$ & $0.010(0.004)$ & 0.87 \\
& $140 / 5$ & $2.14(0.14)$ & $0.048(0.003)$ & 0.82 \\
& $140 / 20$ & $2.27(0.12)$ & $0.062(0.003)$ & 0.88 \\
& $280 / 5$ & $2.16(0.16)$ & $0.092(0.006)$ & 0.66 \\
& $280 / 20$ & $2.52(0.15)$ & $0.030(0.002)$ & 0.92 \\
\hline
\end{tabular}

a Parameter descriptions are explained in the text. Estimates of $Q^{\prime}$ were $1.6 \times$ $10^{4} \mathrm{~min}^{-1}\left(\mathrm{SE}=4.1 \times 10^{3}\right)$ for the $11-\mathrm{mm} / \mathrm{h}$ rain intensity and $1.9 \times 10^{4} \mathrm{~min}^{-1}$ $\left(\mathrm{SE}=1.55 \times 10^{3}\right)$ for the $30-\mathrm{mm} / \mathrm{h}$ rain intensity with the bare soil (control). It was assumed that $Q^{\prime}$ was the same for all treatments at the same rain intensity.

b Bare soil (control) and combination of sudangrass planting density (140 or $280 \mathrm{~kg}$ of seeds per ha) and height (5 or $20 \mathrm{~cm}$ ), labeled as density/height.

c Standard error in parentheses.

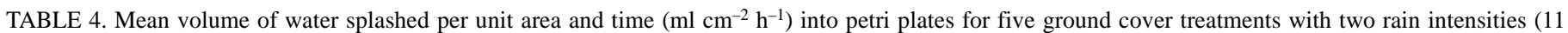
and $30 \mathrm{~mm} / \mathrm{h}$ ) at two times after the start of rain generation (12 and $27 \mathrm{~min}$ )

\begin{tabular}{|c|c|c|c|c|c|c|c|}
\hline \multirow[b]{3}{*}{ Treatment $^{\mathrm{a}}$} & \multicolumn{4}{|c|}{ Intensity } & & & \multirow[b]{3}{*}{ Mean $^{c}$} \\
\hline & \multicolumn{2}{|c|}{$11 \mathrm{~mm} / \mathrm{h}$} & \multicolumn{2}{|c|}{$30 \mathrm{~mm} / \mathrm{h}$} & \multicolumn{2}{|c|}{ Mean $^{\mathrm{b}}$} & \\
\hline & $12 \min$ & $27 \mathrm{~min}$ & $12 \mathrm{~min}$ & $27 \mathrm{~min}$ & $12 \mathrm{~min}$ & $27 \mathrm{~min}$ & \\
\hline Soil & $\begin{array}{l}0.053 \\
(0.007)^{\mathrm{d}}\end{array}$ & $\begin{array}{c}0.044 \\
(0.008)\end{array}$ & $\begin{array}{c}0.076 \\
(0.016)\end{array}$ & $\begin{array}{c}0.084 \\
(0.027)\end{array}$ & $\begin{array}{c}0.064 \\
(0.007)\end{array}$ & $\begin{array}{c}0.064 \\
(0.010)\end{array}$ & $\begin{array}{c}0.064 \\
(0.006)\end{array}$ \\
\hline $140 / 5$ & $\begin{array}{c}0.058 \\
(0.072)\end{array}$ & $\begin{array}{c}0.083 \\
(0.055)\end{array}$ & $\begin{array}{c}0.099 \\
(0.017)\end{array}$ & $\begin{array}{c}0.128 \\
(0.021)\end{array}$ & $\begin{array}{c}0.078 \\
(0.012)\end{array}$ & $\begin{array}{c}0.105 \\
(0.017)\end{array}$ & $\begin{array}{c}0.092 \\
(0.011)\end{array}$ \\
\hline $140 / 20$ & $\begin{array}{c}0.209 \\
(0.050)\end{array}$ & $\begin{array}{c}0.207 \\
(0.059)\end{array}$ & $\begin{array}{c}0.246 \\
(0.007)\end{array}$ & $\begin{array}{c}0.215 \\
(0.008)\end{array}$ & $\begin{array}{c}0.228 \\
(0.038)\end{array}$ & $\begin{array}{c}0.211 \\
(0.027)\end{array}$ & $\begin{array}{c}0.219 \\
(0.022)\end{array}$ \\
\hline $280 / 5$ & $\begin{array}{c}0.049 \\
(0.007)\end{array}$ & $\begin{array}{c}0.055 \\
(0.016)\end{array}$ & $\begin{array}{c}0.118 \\
(0.041)\end{array}$ & $\begin{array}{c}0.127 \\
(0.025)\end{array}$ & $\begin{array}{c}0.084 \\
(0.017)\end{array}$ & $\begin{array}{c}0.091 \\
(0.019)\end{array}$ & $\begin{array}{c}0.087 \\
(0.012)\end{array}$ \\
\hline $280 / 20$ & $\begin{array}{c}0.203 \\
(0.002)\end{array}$ & $\begin{array}{c}0.211 \\
(0.008)\end{array}$ & $\begin{array}{c}0.299 \\
(0.018)\end{array}$ & $\begin{array}{c}0.310 \\
(0.018)\end{array}$ & $\begin{array}{c}0.251 \\
(0.032)\end{array}$ & $\begin{array}{c}0.260 \\
(0.035)\end{array}$ & $\begin{array}{c}0.256 \\
(0.023)\end{array}$ \\
\hline Mean & $\begin{array}{c}0.114 \\
(0.025)\end{array}$ & $\begin{array}{c}0.120 \\
(0.025)\end{array}$ & $\begin{array}{c}0.168 \\
(0.025)\end{array}$ & $\begin{array}{c}0.173 \\
(0.022)\end{array}$ & $\begin{array}{c}0.141 \\
(0.018)\end{array}$ & $\begin{array}{c}0.146 \\
(0.017)\end{array}$ & \\
\hline
\end{tabular}

${ }^{a}$ Bare soil (control) and combination of sudangrass planting density (140 or $280 \mathrm{~kg}$ of seeds per ha) and height (5 or $\left.20 \mathrm{~cm}\right)$, identified with a density/height label.

b Means across the two rain intensities.

${ }^{c}$ Means across the two rain intensities and two times.

${ }^{\mathrm{d}}$ Standard error in parentheses. 
possibly over only a limited range of true water transport values. Our measurements of $R_{S}$ were precise, as indicated by the low standard errors relative to the means (Table 4), and clearly affected by topography. The observed relationship between mean $R_{S}$ and mean estimated $\Sigma$ (cf. Tables 2 and 4) differed from that found in systems without a cover crop (21), demonstrating that a cover crop affects droplet transport in more complicated ways than does simple variation in surface roughness. For instance, $R_{S}$ was lower for the bare soil surface (control) treatment than for the others, even though the greatest dispersal occurred over the bare soil surface. Thus, the increase in roughness of the surface and the barrier effects of the sudangrass plants were negated by other aspects of the system, resulting in increased water splash but lower spore movement. Explanation of the results can be derived from prior studies on canopy transformation of rain.

Raindrop size distribution and rain intensity are altered by plant canopies $(2,11)$. For instance, mean rain intensity is reduced under potatoes and brussels sprouts, except beneath leaf drip points where intensity is higher than average (11). However, kinetic energy of impacting drops may actually increase under a canopy $(27,28,30)$, because energy is proportional to the 4.3 power of drop diameter (32), and drop diameters under and around a canopy are higher than for directly impacting raindrops $(2,27,28)$. With a grass cover crop, a considerable proportion of incident rain is expected to directly penetrate to the soil surface, but some water drops would collect on the leaf surface and eventually drip or be splashed by other drops to the surface. Therefore, dripping water, consisting of many large-diameter drops $(2,27,28,30)$, could increase total kinetic energy of impacting drops on the surface, resulting in an increase in water volume splashed $(48,49)$. This scenario is in agreement with our results. Moreover, water dripping from the taller grass would reach higher velocity and kinetic energy (35) than that dripping from the shorter grass, resulting in greater splash volume, which is also consistent with our results (Table 4). Because the stems and leaves of a cover crop also present a barrier to horizontal transport of water, the increased $R_{S}$ would not necessarily lead to greater net spore movement. For instance, of the four cover crop treatments, the greatest dispersal occurred with the high planting density and tall plants (280/20) and the lowest for the short plants at this density (280/5). However, even though the taller plants at both densities had greater $R_{S}$ than the shorter plants (Table 4), height of sudangrass only influenced dispersal at the $280-\mathrm{kg} / \mathrm{ha}$ planting density. Presumably, the lower density of plants did not provide sufficient contrast of roughness, barrier, and kinetic energy levels between plant heights to observe the effect noted for the higher planting density. Our results also help explain why the greatest spore movement and disease spread occurs at greater than the minimum strawberry planting density $(5,23)$.

Using cover crops between rows as a component of weed management and moisture control and as protection against wind has been successful in various cropping systems including strawberry (33) and raspberry (14). Although a cover crop could conceivably also result in higher disease severity due to changes in microenvironment $(16,17,38)$, beneficial effects of reduced dispersal should be considered, especially for crops in which use of a mulch is standard practice. Mulching is one of the practices used by traditional farmers for managing plant diseases (39). Intercrops and cover crops have also been shown to reduce the intensity of plant diseases $(4,6,43)$. Results found here indicate that alteration in spore dispersal is one mechanism for the observed results. For example, strawberry plants grown in living mulch of ryegrass (Lolium perenne) had less strawberry leaf scorch incidence, caused by Diplocarpon earliana (a splash-dispersed pathogen), than plants in control plots (29). The authors speculated that a windbreak action reduced abrasion and particulate damage to the leaf cuticle and epidermis, although dispersal was not considered. Moreover, a notill wheat cover crop reduced dramatically the incidence of Phytophthora capsici on pepper (36) and the authors assumed that this was due to the effect of the cover crop on splash dispersal. Thus, intercrops or cover crops have the general potential of aiding in the management of plant diseases by reduction in splash dispersal. Field studies will be needed to determine if a cover crop between strawberry rows $(29,33)$ reduces splash dispersal to the same extent as found in this controlled study and if reduced dispersal can negate any possible increases in infection or sporulation that could occur due to cover crop changes to the microenvironment in the field.

\section{ACKNOWLEDGMENTS}

Research support and salaries provided by state and federal funds (especially USDA-NRI competitive grant 95-37303-1788) appropriated to the Ohio Agricultural Research and Development Center (OARDC), The Ohio State University. Journal article 31-98.

\section{LITERATURE CITED}

1. Albregts, E. E., and Howard, C. M. 1994. Strawberry production in Florida. Univ. Fla. Coop. Ext. Serv. Bull. 841.

2. Armstrong, C. L., and Mitchell, J. K. 1987. Transformation of rainfall by plant canopy. Trans. Am. Soc. Agric. Eng. 31:1400-1409.

3. Bailey, J. A., and Jeger, M. J., eds. 1992. Colletotrichum: Biology, Pathology, and Control. CAB International, Wallingford, United Kingdom.

4. Boudreau, M. A. 1993. Effect of intercropping beans with maize on the severity of angular leaf spot of beans in Kenya. Plant Pathol. 42:16-25.

5. Boudreau, M. A., and Madden, L. V. 1995. Effect of strawberry density on dispersal of Colletotrichum acutatum by simulated rain. Phytopathology 85:934-941.

6. Burdon, J. J., and Chilvers, G. A. 1977. Controlled environment experiments on epidemic rates of barley mildew in different mixtures of barley and wheat. Oecologia 28:141-146.

7. Denham, T. G., and Waller, J. M. 1981. Some epidemiological aspects of post-bloom fruit drop disease (Colletotrichum gloeosporioides) in citrus. Ann. Appl. Biol. 98:65-77.

8. Dodd, J. C., Estrada, A. B., Matcham, J., Jeffries, P., and Jeger, M. J. 1991. The effect of climatic factors on Colletotrichum gloeosporioides, causal agent of mango anthracnose, in the Philippines. Plant Pathol. 40:568-575.

9. Dodd, J. C., Estrada, E., and Jeger, M. J. 1992. Epidemiology of Colletotrichum gloeosporioides in the tropics. Pages 308-325 in: Colletotrichum: Biology, Pathology, and Control. J. A. Bailey and M. J. Jeger, eds. CAB International, Wallingford, United Kingdom.

10. Eastburn, D. M., and Gubler, W. D. 1990. Strawberry anthracnose: Detection and survival of Colletotrichum acutatum in soil. Plant Dis. 74:161-163.

11. Finney, H. J. 1984. The effect of crop covers on rainfall characteristics and splash detachment. J. Agric. Eng. Res. 29:337-343.

12. Fitt, B. D. L., Walklate, P. J., McCartney, H. A., Bainbridge, A., Creighton, N. F., Hirst, J. M., Lacey, M. E., and Legg, B. J. 1986. A rain tower and wind tunnel for studying the dispersal of plant pathogens by rain and wind. Ann. Appl. Biol. 109:661-671.

13. Fitzell, R. D., and Peak, C. M. 1984. The epidemiology of anthracnose disease of mango: Inoculum sources, spore production, and dispersal. Ann. Appl. Biol. 104:53-59.

14. Freyman, S. 1989. Living mulch ground covers for weed control between raspberry rows. Acta Hortic. 262:349-356.

15. Funt, R. C. 1994. Ohio Strawberry Production, Management and Marketing Manual. Ohio State University Extension, Columbus.

16. Giesler, L. J., Yuen, G. Y., and Horst, G. L. 1996. Tall fescue canopy density effects on brown patch disease. Plant Dis. 80:384-388.

17. Giesler, L. J., Yuen, G. Y., and Horst, G. L. 1996. The microclimate in tall fescue turf as affected by canopy density and its influence on brown patch disease. Plant Dis. 80:389-394.

18. Huang, C., and Bradford, J. M. 1992. Applications of a laser scanner to quantify soil microtopography. Soil Sci. Soc. J. 56:14-21.

19. Huang, C., White, I., Thwaite, E. G., and Bendeli, A. 1988. A noncontact laser system for measuring soil surface topography. Soil Sci. Soc. J. 52:350-355.

20. Huber, L., Fitt, B. D. L., and McCartney, H. A. 1996. The incorporation of pathogen spores into rain-splash droplets: A modelling approach. Plant Pathol. 45:506-517.

21. Madden, L. V. 1992. Rainfall and the dispersal of fungal spores. Adv. Plant Pathol. 8:39-79.

22. Madden, L. V. 1997. Effects of rain on splash dispersal of fungal pathogens. Can. J. Plant Pathol. 19:225-230.

23. Madden, L. V., and Boudreau, M. A. 1997. Effect of strawberry density on the spread of anthracnose caused by Colletotrichum acutatum. Phytopathology 87:828-838. 
24. Madden, L. V., and Ellis, M. A. 1990. Effects of ground cover on splash dispersal of Phytophthora cactorum from strawberry fruits. J. Phytopathol. 129:170-174.

25. Madden, L. V., Wilson, L. L., and Ellis, M. A. 1993. Field spread of anthracnose fruit rot of strawberry in relation to ground cover and ambient weather conditions. Plant Dis. 77:861-866.

26. Madden, L. V., Yang, X., and Wilson, L. L. 1996. Effects of rain intensity on splash dispersal of Colletotrichum acutatum. Phytopathology 86:864-874.

27. Morgan, R. P. C. 1982. Splash detachment under plant covers: Results and implications of a field study. Trans. Am. Soc. Agric. Eng. 25:987-991.

28. Morgan, R. P. C. 1985. Effect of corn and soybean canopy on soil detachment by rainfall. Trans. Am. Soc. Agric. Eng. 28:1135-1140.

29. Newenhouse, A. C., and Dana, M. N. 1989. Grass living mulch for strawberries. J. Am. Soc. Hortic. Sci. 114:859-862.

30. Noble, C. A., and Morgan, R. P. C. 1983. Throughfall interception and splash detachment with brussels sprouts plant: A laboratory simulation. Earth Surf. Processes Landforms 8:569-577.

31. Ntahimpera, N., Ellis, M. A., Wilson, L. L., and Madden, L. V. 1997. Alteration of rain effects on the splash dispersal of Colletotrichum acutatum by a cover crop. (Abstr.) Phytopathology 87:S70-S71.

32. Ntahimpera, N., Madden, L. V., and Wilson, L. L. 1997. Effect of rain distribution alteration on splash dispersal of Colletotrichum acutatum. Phytopathology 87:649-655.

33. Pritts, M. P., and Kelly, M. J. 1993. Alternative weed management strategies for strawberries. Acta Hortic. 348:321-327.

34. Reynolds, K. M., Bulger, M. A., Madden, L. V., and Ellis, M. A. 1987. New methods using simulated rains to study the splash dispersal of plant pathogens. Phytopathology 77:921-926.

35. Reynolds, K. M., Madden, L. V., Reichard, D. L., and Ellis, M. A. 1987. Methods for study of raindrop impact on plant surfaces with application to predicting inoculum dispersal by rain. Phytopathology 77:226-232.

36. Ristaino, J. B., Para, G., and Campbell, C. L. 1997. Suppression of Phytophthora blight in bell pepper by a no-till wheat cover crop. Phytopathology 87:242-249.

37. Romkens, M. J. M., and Wang, J. Y. 1987. Soil roughness changes from rainfall. Trans. Am. Soc. Agric. Eng. 30:101-107.

38. Schnathorst, W. C. 1965. Environmental relationships in powdery mildews. Annu. Rev. Phytopathol. 3:343-366.

39. Thurston, H. D. 1990. Plant disease management practices of traditional farmers. Plant Dis. 74:96-102.

40. Trenbath, B. R. 1993. Intercropping for the management of pests and diseases. Field Crops Res. 34:381-405.

41. Ulbrich, C. W. 1983. Natural variations in the analytical form of the raindrop distribution. J. Clim. Appl. Meteorol. 22:1764-1775.

42. Vandermeer, J. 1989. The Ecology of Intercropping. Cambridge University Press, Cambridge, United Kingdom.

43. van Rheenen, H. A., Hasselbach, O. E., and Muigai, S. S. G. 1981. The effect of growing beans together with maize on incidence of bean diseases and pests. Neth. J. Plant Pathol. 87:193-199.

44. Walklate, P. J., McCartney, H. A., and Fitt, B. D. L. 1989. Vertical dispersal of plant pathogens by splashing. Part II. Experimental study of the relationship between raindrop size and the maximum splash height. Plant Pathol. 38:64-70.

45. Wilson, L. L., Madden, L. V., and Ellis, M. A. 1990. Influence of temperature and wetness duration on infection of immature and mature strawberry fruit by Colletotrichum acutatum. Phytopathology 80:111-116.

46. Yang, X., and Madden, L. V. 1993. Effect of ground cover, rain intensity, and strawberry plants on splash of simulated raindrops. Agric. For. Meteorol. 65:1-20.

47. Yang, X., Madden, L. V., and Brazee, R. D. 1991. Application of the diffusion equation for modelling splash dispersal of point source pathogens. New Phytol. 118:295-301.

48. Yang, X., Madden, L. V., Reichard, D. L., Fox, R. D., and Ellis, M. A. 1991. Motion analysis of drop impaction on a strawberry surface. Agric. For. Meteorol. 56:67-92.

49. Yang, X., Madden, L. V., Wilson, L. L., and Ellis, M. A. 1990. Effects of surface topography and rain intensity on splash dispersal of Colletotrichum acutatum. Phytopathology 80:1115-1120.

50. Yang, X., Wilson, L. L., Madden, L. V., and Ellis, M. A. 1990. Rain splash dispersal of Colletotrichum acutatum from infected strawberry fruit. Phytopathology 80:590-595. 